\title{
Addisonian-like acrofacial hyperpigmentation following long-term hydroxychloroquine therapy in oral lichen planus
}

\author{
Dibyendu Bikash Bhanja, ${ }^{1}$ Abheek Sil, ${ }^{1}$ Atanu Chandra 다. ${ }^{2}$ Surajit Kumar Biswas ${ }^{1}$
}

'Dermatology, Venereology, Leprosy, RG Kar Medical College and Hospital, Kolkata, West Bengal, India

${ }^{2}$ Internal Medicine, RG Kar Medical College and Hospital, Kolkata, West Bengal, India

\section{Correspondence to} Dr Atanu Chandra; chandraatanu123@gmail.com

Accepted 14 January 2021

\section{DESCRIPTION}

A 50-year-old woman, Fitzpatrick skin type 5, presented with a 1 year history of asymptomatic hyperpigmentation over face and extremities. She was taking hydroxychloroquine (HCQ) $200 \mathrm{mg}$ / day for the past 3 years for the treatment of oral lichen planus, as prescribed by her primary physician. There was no history of weakness, postural hypotension, altered bowel habits, pain abdomen, sensation of tingling or numbness, photosensitivity, diabetes mellitus or any suggestive systemic symptom. Cutaneous examination revealed poorly demarcated greyish-black coalescent macules and patches distributed over face, sides of neck, oral cavity, both hands (with accentuation over skin overlying joints and palmar involvement) and dorsa of feet (figure 1). Well-defined plaques with white lacy pattern, characteristic of lichen planus, were visible over lower lip, tongue and buccal mucosa. Other mucocutaneous sites were unaffected and systemic examination was unremarkable. A comprehensive ophthalmological examination did not show any evidence of retinopathy. Biochemistry panels comprising complete haemogram with peripheral blood smear, serum vitamin $B_{12}$, folic acid, cortisol, electrolytes, iron, fasting blood sugar, liver function tests, renal and thyroid profile were within normal limits. Serology for human immune deficiency virus, viral hepatitis markers and syphilis was negative. Skin biopsy was planned but refused by the patient. HCQ was withdrawn. Gradual improvement in pigmentation was appreciated over the subsequent 6 months. The causal relationship between HCQ and hyperpigmentation was found to be 'probable' according to the objective causality assessment by the Naranjo probability scale (Naranjo score $=6$ ). Suggestive history, distinctive clinical features and temporal association with HCQ established the diagnosis of HCQ-induced cutaneous hyperpigmentation.

HCQ is one of the most frequently used drugs in dermatology with a wide variety of uses due to its immunomodulatory, anti-inflammatory, photoprotective, anti-infective and metabolic actions. Apart from ocular complications, long-term use of HCQ is associated with a bluish-grey to black hyperpigmentation and progressive bleaching of the hair roots of the scalp. ${ }^{1}$ Tuffanelli et al suggested that pigmentation could be a marker for ocular side effects. $^{2}$ Although HCQ-induced hyperpigmentation is reported in 7\%-29\% of patients of systemic lupus erythematosus, it has rarely been documented in lichen planus patients. ${ }^{3}$ HCQ acts in oral lichen planus, by concentrating in the cytoplasm of antigen-presenting cells; thereby elevating intravesicular $\mathrm{pH}$, downregulating immune response as well as modulating Treg-related gene expression. ${ }^{4}$ The pigmentation predominates over the face, shins, palate and nailbeds (as transverse bands). The onset of HCQ-associated hyperpigmentation ranges from 3 months to 22 years following the initiation of therapy, with a median of 6.1 years. The exact mechanism of hyperpigmentation is poorly understood; however, it has been hypothesised that ecchymosis or easy bruising conditions (use of anticoagulants or antiplatelet agents, prolonged use of corticosteroids, skin trauma or antiphospholipid syndrome) may act as precipitating factors. ${ }^{5}$ HCQ-induced hyperpigmentation ought to be differentiated from other systemic causes of hyperpigmentation (vitamin $\mathrm{B}_{12}$ deficiency, Addison's disease, Cushing's disease, hypo or hyperthyroidism,
A) Check for updates

(C) BMJ Publishing Group Limited 2021. No commercial re-use. See rights and permissions. Published by BMJ.

To cite: Bhanja $D B$, Sil $A$, Chandra A, et al. BMJ Case Rep 2021;14:e240727. doi:10.1136/bcr-2020240727

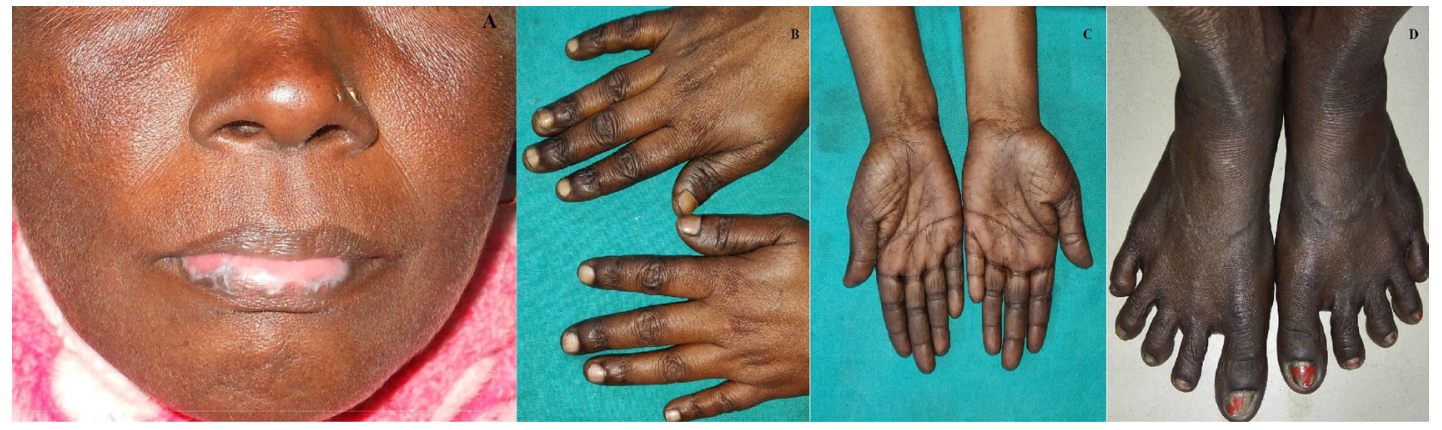

Figure 1 Poorly demarcated greyish-black coalescent macules and patches distributed over face (lichen planus over lip to be noted) (A). Hyperpigmentation over both hands (with accentuation over skin overlying joints and palmar involvement) and dorsa of feet (B-D). 
haemochromatosis), melasma, lichen planus pigmentosus, other drug reactions (chlorpromazine, amiodarone, minocycline) and argyria. Discontinuation of HCQ leads to gradual decrease of hyperpigmentation within several months. ${ }^{15}$

Physician should be aware of this cutaneous side effect of long-term HCQ usage and ensure prompt ophthalmological assessment to rule out associated ocular complications.

\section{Learning points}

Long-term use of hydroxychloroquine (HCQ) is associated with bluish to grey pigmentation especially in patients diagnosed with systemic lupus erythematosus. HCQ-induced hyperpigmentation in oral lichen planus has rarely been documented.

- HCQ-induced hyperpigmentation typically demonstrates generalised cutaneous involvement. Acrofacial distribution, mimicking addisonian pigmentation, is an uncommon presentation.

- Prompt ophthalmological examination should be carried out in patients suspected with HCQ-induced hyperpigmentation to rule out its ocular side effects. Pigmentation could be a marker for ocular toxicity.

Contributors DBB prepared the manuscript with adequate planning and execution; he also collected data regarding the patient. AS was a direct care giver to the patient, who managed the case actively and collected relevant data on investigations with equal contributorship. He also helped in preparing the manuscript. His planning and analysis of the case helped in formulating the report. AC helped in detailed supervision, final output and review of literature regarding the manuscript. SKB supervised the entire management of the patient and has actively contributed in editing the manuscript. All authors are in agreement to be accountable for all aspects of the work in ensuring that questions related to the accuracy or integrity of any part of the work are appropriately investigated and resolved.

Funding The authors have not declared a specific grant for this research from any funding agency in the public, commercial or not-for-profit sectors.

Competing interests None declared.

Patient consent for publication Obtained.

Provenance and peer review Not commissioned; externally peer reviewed.

\section{ORCID iD}

Atanu Chandra http://orcid.org/0000-0002-3809-8926

\section{REFERENCES}

1 Kumar S, Sil A, Das A. Hydroxychloroquine for COVID-19: myths vs facts. Dermatol Ther 2020;33:e13857.

2 Tuffanelli D, Abraham RK, Dubois El. Pigmentation from antimalarial therapy. its possible relationship to the ocular lesions. Arch Dermatol 1963;88:419-26.

3 Bahloul E, Jallouli M, Garbaa S, et al. Hydroxychloroquine-Induced hyperpigmentation in systemic diseases: prevalence, clinical features and risk factors: a cross-sectional study of 41 cases. Lupus 2017:26:1304-8.

4 Zhu Y, Li J, Bai Y, et al. Hydroxychloroquine decreases the upregulated frequencies of Tregs in patients with oral lichen planus. Clin Oral Investig 2014;18:1903-11.

5 Jallouli $M$, Francès $C$, Piette J-C, et al. Hydroxychloroquine-Induced pigmentation in patients with systemic lupus erythematosus: a case-control study. JAMA Dermatol 2013:149:935-40.

Copyright 2021 BMJ Publishing Group. All rights reserved. For permission to reuse any of this content visit

https://www.bmj.com/company/products-services/rights-and-licensing/permissions/

BMJ Case Report Fellows may re-use this article for personal use and teaching without any further permission.

Become a Fellow of BMJ Case Reports today and you can:

- Submit as many cases as you like

- Enjoy fast sympathetic peer review and rapid publication of accepted articles

- Access all the published articles

Re-use any of the published material for personal use and teaching without further permission

Customer Service

If you have any further queries about your subscription, please contact our customer services team on +44 (0) 2071111105 or via email at support@bmj.com.

Visit casereports.bmj.com for more articles like this and to become a Fellow 